Thus, determined not to allow the $B M \mathcal{F}$ to vanish needlessly, Hugh Clegg called an editorial meeting round the candle in his room, and we began work on the issue dated 22 February 1947. Meanwhile he had obtained assurances from the Secretary that his staff would be available for cyclostyling the $B M \mathcal{F}$ and dispatching it without the use of any fuel except candles. To make this possible the Editor decided that the whole issue should be on a single sheet of foolscap paper, cyclostyled on both sides. We thereupon reduced news items to a line or so, letters to "Points," obituaries to name, age, and a sentence, and advertisements for hospital appointments (one of our most essential services) to much abbreviated but what we hoped were unambiguous announcements. Finally, a leading article drew attention to the fact that coal is a source of medicine as well as of power, for its constituents had given us carbolic acid, dyestuffs from which the sulphonamides had been synthesised, synthetic antimalarials, aspirin, and stilboestrol. The text of the whole issue was then carefully cut on a series of stencils, from these the cyclostyled sheets were printed, and some 62000 copies were put into envelopes, addressed, and dispatched. The journal staff were grateful to the Secretariat for running this operation so willingly and smoothly.

As the fuel crisis continued, it became apparent that another issue of the $B M F$ would be needed on the same lines. So for 1 March we prepared the second "pemmican" issue, as they were called-from the American Indian word for a cake of dried and pounded meat mixed with currants for travellers in the Arctic $(O E D)$. This time the leader was on "freedom to print." The theme touched on here was that "the freedom of the press is not a privilege of the newspaper but a fundamental liberty of the subject." Once again willing hands in the BMA Secretariat cyclostyled and dispatched the entire issue without the use of fuel.

Thereafter the fuel crisis subsided, the weather improved, our feet warmed up, our breath was less cloudy on the air, and a shoal of congratulatory letters flooded in. A selection could be published in succeeding issues of the journal in its customary form once again. Among those letters was one from Sir Ernest Graham-Little, ${ }^{1}$ a Tory MP with a medical degree, who exposed the confusion in Parliament and outside over the nature of the ban on publication. As he pointed out, the Prime Minister (Clement Attlee) speaking in the Commons and Lord Chorley speaking for the Government in the Lords had put out rather different versions of the Government's actions. Furthermore, according to the Prime Minister it was done by agreement with the PPA, ${ }^{2}$ but Graham-Little said that the instruction was in fact issued "three days before any consultation with the PPA was attempted." That the Government acted, and then tried to justify its actions, in a casually high-handed manner seems plain. Graham-Little also suggested that it might have been convenient to ministers to silence the medical journals during negotiations in progress on the projected national health service, and he observed that, "The possibility of such back-stage ministerial intrigues lends a sinister significance to this new encroachment on our liberties." This, however, was going a bit far: experienced politicians would surely not have intrigued so ineptly.

No doubt the episode was a small crackle in a sky lurid with the fireworks of a world trying to rebuild itself from the ruins of war, but to me at least the Editor's action on that occasion has always seemed to be as percipient as it was resolute. Democratic parliamentary rule had been established at Westminster again after its virtual suspension for six years. Nearly everyone accepted the continued need for rationing at that time, but the feeling was also strong that the Government must govern under the law and that a vigilant press was needed to ensure that it did so. We had spent over five years fighting against murderously efficient tyrannies, and for part of that time we had perforce been the admiring allies of a tyranny as deadly as those we fought. Western parliamentary democracy was-and perhaps still is-a frail vessel on a stormy sea, and the abuse of its powers by our own Government seemed to us on the $B M F$ to contain a hint of all that we most detested. A reader today who thinks that must be an exaggerated view makes his judgment from a different perspective, for the most obvious threat to parliamentary democracy in this country now comes from those trade unions and other bodies outside Parliament who attempt to destroy governments by extraparliamentary means. But in 1947 a vast web of wartime controls still persisted, on the whole with the nation's consent, and the slightest misuse of them by the Government needed to be challenged.

Perhaps I may end on a personal note. My wife and I sometimes recall the great fuel crisis with wry amusement, for between the production of the two pemmican issues of the $B M F$ she gave birth to our first baby.

\section{References}

1 Graham-Little E. The pemmican BMf. Br Med f 1947 ;i:349.

${ }^{2}$ Medical Notes in Parliament. Br Med $\mathscr{f} 1947 ; \mathrm{i}: 317$.

(Accepted 2 fuly 1980)

\title{
As others see us
}
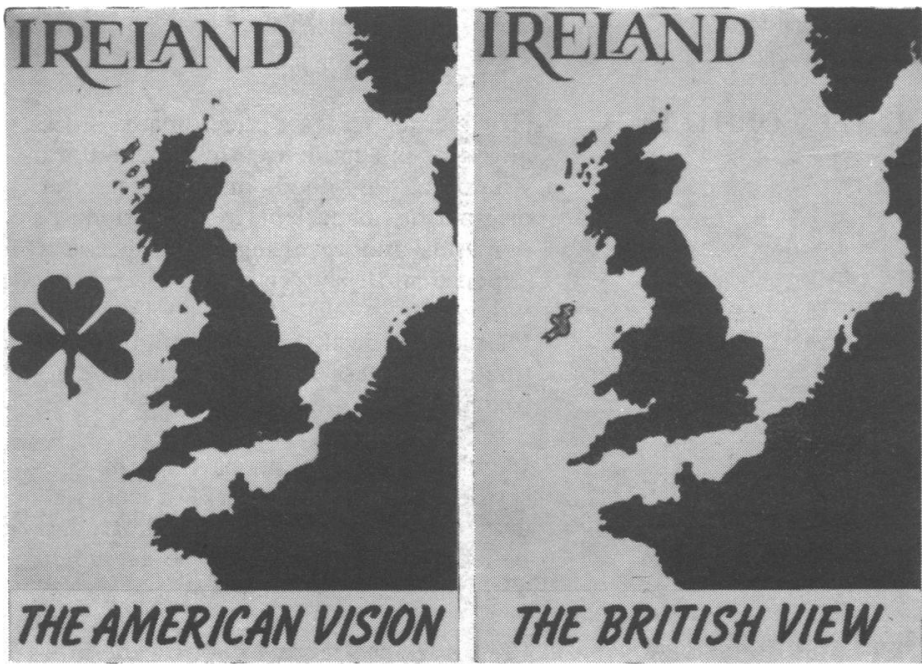
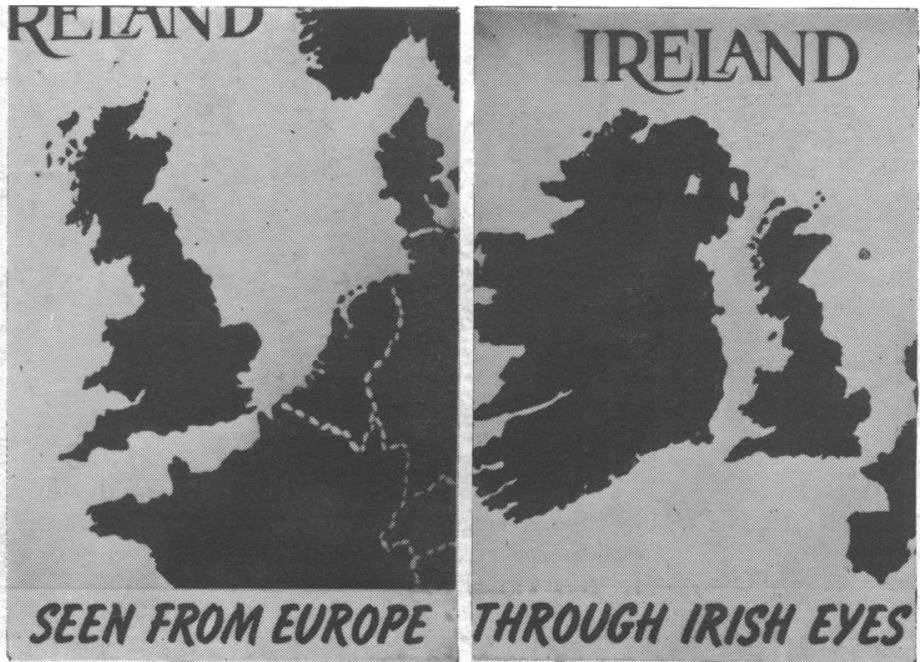